\section{Growth and dry matter partition wheat plants in response to seed vigor and water restriction}

\author{
Felipe Koch ${ }^{1}$ (D) Jessica Mengue Rolim*1 (D), Emanuela Garbin Martinazzo ${ }^{2}$ (D), \\ Tiago Pedó ${ }^{1}$ (D) Francisco Amaral Villela ${ }^{1}$ (D) Tiago Zanatta Aumonde ${ }^{1}$
}

\begin{abstract}
The quality of the seeds and the occurrence of stresses are decisive for the development of the crops. Thus, the work aimed to verify the effect of seed vigor on growth and dry weight partition of wheat plants subjected to water stress. For growth evaluation, the experimental design was completely randomized, in a $2 \times 2 \times 8$ factorial scheme (vigor level $x$ water regime $x$ collection time), with four replications. To evaluate the yield of the seeds, the design was completely randomized, in a $2 \times 2$ factorial scheme (level of vigor $x$ water regime), with four replications. Total dry weight, dry weight production rate, relative growth rate, leaf area ratio, leaf area, solar energy conversion efficiency, dry weight partition and harvest index were evaluated. Total dry weight production, dry weight production rate, leaf area, leaf weight ratio, solar energy conversion efficiency and yield were higher for plants from highly vigorous seeds under field capacity. The yield was higher for plants with high vigor compared to those with low vigor in field capacity.
\end{abstract}

Index terms: Triticum aestivum L., abiotic stress, vigor, water deficit.

RESUMO: A qualidade das sementes e a ocorrência de estresses são determinantes para o crescimento e desenvolvimento das culturas. Assim, o trabalho teve como objetivo verificar o efeito do vigor das sementes no crescimento e na partição de massa seca de plantas de trigo submetidas a condições de estresse hídrico. Para avaliação do crescimento o delineamento experimental foi inteiramente casualizado, em esquema fatorial $2 \times 2 \times 8$ (nível de vigor $\mathrm{x}$ regime hídrico $\mathrm{x}$ época de coleta), com quatro repetições. Para avaliação do rendimento de grãos, o delineamento foi inteiramente casualizado, em esquema fatorial $2 \mathrm{x}$ 2 (nível de vigor $x$ regime hídrico), com quatro repetições. Foram avaliadas massa seca total, taxa de produção de massa seca, taxa de crescimento relativo, razão de área foliar, área foliar, eficiência de conversão da energia solar, partição de massa seca e índice de colheita. A produção de massa seca total, a taxa de produção de massa seca, taxa assimilatória líquida, área foliar, razão de massa foliar, eficiência de conversão da energia solar e rendimento foram superiores para plantas provenientes de sementes de alto vigor sob capacidade de campo. $\mathrm{O}$ rendimento foi superior para plantas de alto vigor em relação àquelas de baixo vigor na capacidade de campo.

Termos para indexação: Triticum aestivum L., estresse abiótico, vigor, déficit hídrico.
Journal of Seed Science, v.43, e202143019, 2021

http://dx.doi.org/10.1590/ 2317-1545v43239171
*Corresponding autho E-mail: eng.jessicarolim@gmail.com

Received: 6/5/2020. Accepted: 7/6/2021.

1Programa de Pós-Graduação em Ciência e Tecnologia de Sementes, Universidade Federal de Pelotas, Faculdade de Agronomia Eliseu Maciel, Departamento de Fitotecnia, Caixa Postal 354, 96010-900 Pelotas, Rio Grande do Sul, Brasil.

${ }^{2}$ Universidade Federal do Rio Grande, ICB, Instituto de Ciências Biológicas - Rio Grande, Rio Grande do Sul, Brasil. 


\section{INTRODUCTION}

Wheat (Triticum aestivum L.) is considered as one of the most cultivated crops on the planet, being a cereal of great importance in the global economy, as it contributes with approximately one fifth of the total calories consumed by humans (Santos et al., 2016; Goergen et al., 2017; Appels et al., 2018). However, Brazilian wheat production does not meet the demand for high consumption of seeds of this species, which are also of great importance in the animal diet (Borém and Scheeren, 2015).

Due to this production deficit, it is necessary to import the product. Notably, alternatives are needed to achieve selfsufficiency in wheat production, among which, the increase in yield and the expansion of the cultivated area (Oliveira et al., 2011; Borém and Scheeren, 2015).

In this sense, the expression of the seed yield potential depends on genetic and environmental factors, in addition to the interaction between both, which results in differences considered in the performance of plants when grown under different environmental conditions (Yan and Holland, 2010). Therefore, biotic and abiotic stresses, as well as soil fertility and phytosanitary management can be directly linked to low crop yields.

In this sense, the seeds used in the implantation of a crop have a direct influence on the yield. According to Munizzi et al. (2010) seeds of high physiological quality have higher speed in metabolic processes, which provides faster and more uniform germinations. Thus, the use of high-quality seeds allows to obtain plants of superior performance, capable of presenting superior responses even when exposed to environmental conditions not considered optimal.

This ability to establish plants even when in unfavorable conditions is directly linked to the vigor of the seeds used, which is defined by the properties of the seeds that determine the potential for germination, emergence and adequate development and in less time for normal plants under a wide variety environmental characteristics, among them the edaphoclimatic conditions and characteristics of the place of cultivation (Simoni et al., 2011).

Several factors can directly influence the development and yield of crops, such as the occurrence of stresses, whether they are of abiotic origin, such as those caused by edaphoclimatic weather conditions, or of biotic origin, such as the incidence of pests and diseases, for example. In this context, stress due to water restriction is defined as one of the most relevant obstacles in the production of agricultural crops, limiting the growth of plants and consequently reducing their yields (Meng et al., 2016; Asgher et al., 2017; Hussain et al., 2018). According to Lisar et al. (2012), water stress can cause losses of up to $50 \%$ in world agriculture, without considering the occurrence of extreme events.

Due to water scarcity, plants can produce responses such as stomatal closure, inhibition of leaf expansion, leaf abscission and even changes in root development and architecture (Sinmontacchi et al., 2015). The root system is altered by modifying the growth of roots in order to better absorb water, which during stress is present in a reduced amount in the soil. Thus, characteristics such as the length, weight, density and volume of the root system are directly related to water availability and the species tolerance to cultivation conditions (Hu and Xiong, 2014).

In addition to changes in the root system, plants may also show changes in the aerial part, due to the impairment of the process of photosynthesis and cellular metabolism in general. The reduction of water in the cultivation environment, induces stomatal closure of the leaves in order to reduce the loss of water (Teixeira et al., 2015), which promotes increased leaf temperature and reduced gas exchange (Furlan et al., 2012). In this sense, the decrease in stomatal conductance also causes a reduction in the $\mathrm{CO}_{2}$ supply into the chloroplasts (Tatagiba et al., 2015), which causes a decrease in the photosynthetic rate and leads to a lower accumulation of biomass by the plant (Gallé et al., 2011).

As an option to study plant responses to abiotic stress conditions, growth analysis can be used since it is a low-cost and accurate quantitative method used for evaluating plant growth over time in face of different crop management conditions (Radford, 1967; Lopes and Lima, 2015; Aumonde et al., 2017). Growth analysis consists of sampling at regular intervals, such as leaf area, dry weight, height and diameter. It is possible to estimate some growth rates, such as dry weight production rate, relative growth, net assimilation rate, among others, which allows to establish direct relationship with the final crop yield. 
From the above, the use of high vigor seeds, even under water restriction, can provide plants with a greater efficiency in the use of resources from the growing environment and a higher capacity of dry weight accumulation, mainly during the initial crop growth period. Thus, it may result in plants with a greater productive capacity even when exposed to intermittent water restriction.

Hence, the objective of this work is to verify the effect of seed vigor on growth and dry weight partition of wheat plants subjected to water restriction.

\section{MATERIAL AND METHODS}

\section{Location, soil characteristics, crop maintenance}

The work was conducted in a greenhouse, arranged north-south, located at $31^{\circ} 48^{\prime} 15.12^{\prime \prime} \mathrm{S}$ and $52^{\circ} 24^{\prime} 55.1874^{\prime \prime} \mathrm{W}$, and altitude of $13 \mathrm{~m}$.

The sowing was made in polyethylene pots with an individual capacity of twelve liters. Ten seeds were distributed into each pot. After seedling emergence, it was done a thinning in order to keep four plants in each pot. Each plant corresponded to one replicate. Basic seeds of the cultivar Tbio Toruk were used, which were provided by a company that produces wheat seeds.

As substrate, soil classified as Albaqualf (USDA, 1999) was used. The physical and chemical characteristics are as follows: $\mathrm{pH}\left(\mathrm{H}_{2} \mathrm{O}\right): 4.5, \mathrm{P}: 5.9 \mathrm{mg} \cdot \mathrm{dm}^{-3}, \mathrm{~K}: 38 \mathrm{mg} \cdot \mathrm{dm}^{-3}, \mathrm{Ca}: 13.3 \mathrm{cmol}_{\mathrm{c}} \cdot \mathrm{dm}^{-3}, \mathrm{Mg}: 0.3 \mathrm{cmol}_{\mathrm{c}} \cdot \mathrm{dm}^{-3}, \mathrm{Al}: 1.0 \mathrm{cmol}_{\mathrm{c}} \cdot \mathrm{dm}^{-3}, \mathrm{Cu}$ : $0.1 \mathrm{mg} \cdot \mathrm{dm}^{-3}, \mathrm{Zn}: 0.8 \mathrm{mg} . \mathrm{dm}^{-3}, \mathrm{Mn}: 32 \mathrm{mg} . \mathrm{dm}^{-3}, \mathrm{CEC}: 16.2 \mathrm{cmolc} \mathrm{dm}^{-3}$, base saturation: $85 \%$, organic matter: $0.83 \%$, and clay: $15 \%$. Correction and fertilization were performed following recommendations of the Manual of Fertilization and Liming of the States of Rio Grande do Sul and Santa Catarina (CQFS, 2004).

Soil correction consisted of $0.75 \mathrm{~kg} \cdot \mathrm{dm}^{3}$ of limestone, PRNT $60 \%$, which was incorporated into the soil thirty days before sowing. The basic fertilization was performed pre-sowing, consisting of $0.011 ; 0.024$, and $0.017 \mathrm{~kg} . \mathrm{dm}^{3}$ of $\mathrm{N}$, $\mathrm{P}$ and $\mathrm{K}$, respectively. Two cover nitrogen applications of 0.035 and $0.020 \mathrm{~kg} . \mathrm{m}^{3}$ were performed. The sources were urea $(45 \%)$, triple superphosphate $(41 \%)$, and potassium chloride $(58 \%)$ for nitrogen, phosphorus and potassium, respectively. Pest and disease control was carried out in a preventive manner as recommended for the crop.

\section{Experimental design}

In the plant growth experiment, the design was completely randomized in a $2 \times 2 \times 8$ factorial design (seed vigor level $x$ water regime $x$ collection season) with four replications. The treatments consisted in the combination of two levels of seeds vigor (high and low), two water regimes (field capacity and water restriction during the vegetative and reproductive phases), and eight sampling periods (14, 28, 42, 56, 72, 84, 98 and 112 days).

While in the plant yield experiment, the design was completely randomized in a $2 \times 2$ factorial design (seed vigor level $\mathrm{x}$ water regime) with four replications. The treatments consisted in the combination of two levels of seeds vigor (high and low) and two water regimes (field capacity and water restriction during the vegetative and reproductive phases).

\section{Characterization of seed lots}

The different seed vigor levels were obtained by high temperature and high humidity conditions using the modified accelerated aging method. It consists in placing seeds on a metallic screen fixed inside plastic boxes ("gerbox") containing a $40 \mathrm{~mL}$ saturated saline solution blade ( $40 \mathrm{~g}$ of $\mathrm{NaCl}$ in $100 \mathrm{~mL}$ of water) (Pedroso et al., 2010). The plastic boxes containing the seeds were kept in a BOD chamber at $43^{\circ} \mathrm{C}$ (Lima et al., 2006).

Using the initial seed lots with high vigor, the modified accelerated aging periods were determined to obtain low vigor lots using pre-tests. Thus, the aging period used was 108 hours. The high vigor seed lot was not subjected to accelerated aging.

After the ranking of the lots, the quality of the seeds was verified, with the intention of maintaining lots with 
statistically identical germination, however, with different levels of vigor. For this, a germination test was performed using four samples with four subsamples of fifty seeds per treatment. The seeds were arranged to germinate in rolls composed of three sheets of germinating paper moistened 2.5 times the mass of the dried substrate. The rolls were kept in a BOD germination chamber at $20^{\circ} \mathrm{C}$ and a 12 hour photoperiod. The evaluation of the percentage of normal seedlings was performed eight days after sowing (Brasil, 2009).

In addition, to evaluate the seed vigor of each lot, the field emergence test was used. It consisted in four samples of a hundred seeds per treatment. The sowing was performed in the soil in a spacing of $0.17 \mathrm{~m}$ between lines and a sowing depth of $3 \mathrm{~cm}$. The evaluation was performed 21 days after sowing, and the results were expressed as percentage of normal emerged seedlings.

\section{Water conditions}

The water supply to the plants was performed so that soil moisture was kept at field capacity. For treatments consisting of water restriction, two periods without irrigation were imposed during the plant cycle. The first period of water restriction occurred during the vegetative phase (booting), at the growth stage 45 (Zadoks et al., 1974), 72 days after sowing (DAS). The second period of water restriction occurred during the reproductive phase (seed filling) thirteen days after anthesis, corresponding to growth stage 71 (Zadoks et al., 1974), 97 days after sowing. The suspension of irrigation was kept until the leaf relative water content reached values close to $45 \%$ to the twelve days (vegetative stage) and six days (reproductive stage) after the beginning of water restriction, the irrigation was resumed normally until the end of the plant cycle (Santos et al., 2012).

During the periods of water restriction and rehydration of plants, the leaf relative water content was monitored. For the measurements of relative water content, successive leaf collections were performed. The collections were always carried out in the first hours of the morning and at regular intervals of 48 hours. The relative water content analysis was performed according to the methodology of Barrs and Weatherley (1962). The results were expressed as percentage.

\section{Plant growth and partition of assimilates}

Collections for growth evaluation were performed after emergence in equidistant periods at regular intervals of fourteen days. At each sampling, the whole plant was harvested. Then, the different structures of plants (leaves, stem, roots, and spikes) were separated. To obtain dry weight, samples were packaged separately in brown paper envelopes, and later dried in a forced air ventilation oven at $70 \pm 2{ }^{\circ} \mathrm{C}$ until constant weight.

Primary data on leaf area $\left(\mathrm{L}_{\mathrm{a}}\right)$, dry leaf matter $\left(\mathrm{W}_{\mathrm{l}}\right)$, stem $\left(\mathrm{W}_{\mathrm{s}}\right)$, roots $\left(\mathrm{W}_{\mathrm{r}}\right)$, and seeds $\left(\mathrm{W}_{\mathrm{g}}\right)$ were fitted by orthogonal polynomials (Richards, 1969). The values for total dry matter production rate $\left(C_{t}\right)$ were obtained by time derivatives of adjusted equations of total dry matter $\left(W_{t}\right)$ (Radford, 1967). For the determination of instantaneous values of the relative growth rate $\left(R_{w}\right)$, the equation used was $R_{w}=1 / W_{t} \cdot d_{w} / d_{t}$ and the instantaneous values of the net assimilation rate $\left(E_{a}\right)$, leaf area ratio $\left(F_{a}\right)$, and leaf weight ratio $\left(F_{w}\right)$ were estimated by the equations $E_{a}=1 / L_{a} \cdot d_{w} / d_{t}$ and $F_{a}=L_{a} / W_{t} ;$ $F_{w}=W_{f} / W_{t}$ (Radford,1967).

The primary dry weight accumulated data $\left(W_{t}\right)$ were adjusted by the simple logistic equation $W_{t}=W_{m} /\left(1+A e^{-B t}\right)$, where $W_{m}$ is the asymptotic maximum growth estimate, " $A$ " and " $B$ " are fitting constants, " $e$ " is the natural basis of naperian logarithm, and " $\mathrm{t}$ " is the time in days after emergence (Richards, 1969).

The efficiency of the solar energy conversion $(\xi)$ was determined by the equation $\xi(\%)=(100 . C t . \delta) / R_{s^{\prime}}$, where $R_{s}$ is the mean value of the incident solar radiation $\left(\right.$ cal. $\mathrm{m}^{-2}$. day $\mathrm{y}^{-1}$ ) ten days before the corresponding $\mathrm{C}_{\mathrm{t}^{\prime}}$ and $\delta$ is the calorific value of 4,421.61 cal.g-1 (Demirbas, 2003).

The assessments and acronyms of growth analysis follow the precepts and determinations of Radford (1967) and Richards (1969) that employs classical growth analysis adopted in plant physiology (Lopes and Lima, 2015).

The dry weight partition between the different plant structures (roots, stem, leaves and spikes) during the plant cycle was determined separately by measuring the weight allocated to each plant structure followed by transformation of primary dry weight allocation data of each part into percentage. 
Seed yield

The determination of yield was made by the characterization of the harvest index $(\mathrm{HI})$ determined by the equation $\mathrm{HI}=\mathrm{W}_{\mathrm{g}} / \mathrm{W}_{\mathrm{t}}$, where $\mathrm{W}_{\mathrm{g}}$ is the seeds dry weight, and $\mathrm{W}_{\mathrm{t}}$ is total plant dry weight.

\section{Statistical analysis}

Primary growth data were subjected to analysis of variance by $\mathrm{F}$ test at $5 \%$ and analyzed by simple logistic equation. Values of assimilated partition were converted into percentage (Lopes and Lima, 2015; Aumonde et al., 2017).

Data referring to the study of plant yield were subjected to analysis of variance by $\mathrm{F}$ test at $5 \%$ probability, and, when significant, subjected to analysis of means by Tukey test at $5 \%$ probability.

\section{RESULTS AND DISCUSSION}

The seed germination of the different lots was similar to each other, varying between 93 and $88 \%$. The seed vigor was different among the lots. The high vigor was $85 \%$ and the low was $60 \%$.

The values of relative leaf water content (RWC) of the plants of all treatments, referring to the periods when plants were exposed to different water regimes, are shown in Figure 1. Plants grown from high and low vigor seeds kept at field capacity, maintained values of RWC between 84 and $96 \%$ in both periods. On the other hand, plants grown from high and low vigor seeds exposed to water restriction decreased RWC values gradually with the increase in periods without irrigation, reaching approximately $40 \%$ during both the vegetative and the reproductive phases.

Santos et al. (2012) found similar results, in which was observed a reduction in the relative water content in the leaf of the plants, due to the water deficit. The reduction in the RWC of the plants indicates that the stress condition affected the water content in the leaves. In addition, the occurrence of RWC reduction according to the intensification of water restriction, suggests a dehydration of plant protoplasm, which can culminate in vital changes in cell growth (Langaro, 2014). According to Carvalho et al. (2011) the loss of water in plant tissues can result in a reduction in the chemical potential or water activity, increase the concentration of low molecular weight solutes and macromolecules, in addition to altering the spatial arrangement of organelles and membranes, decreasing their volume and reducing the hydrostatic pressure inside the cells, thus altering all cellular machinery, which can effectively contribute to negative changes in crop growth and yield.
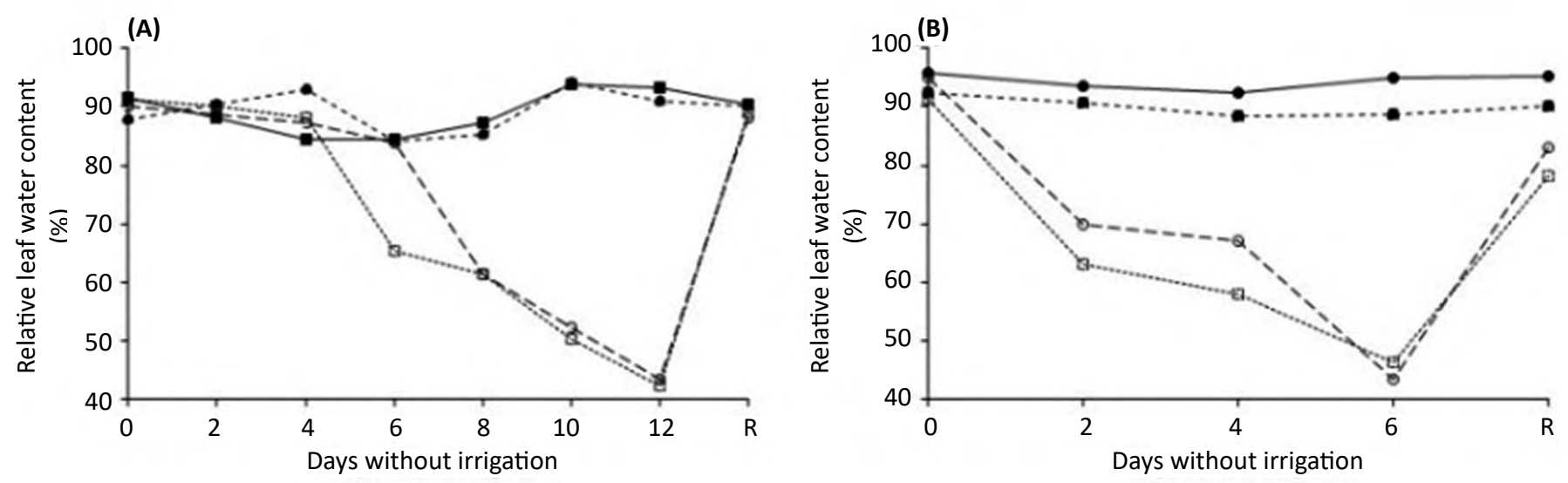

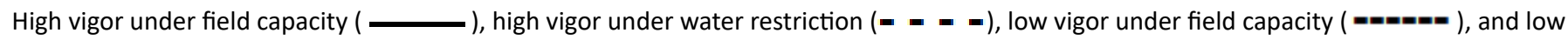
vigor under water restriction ( .......).

Figure 1. Relative water content in leaves of plants grown from seeds with different vigor levels subjected to different water regimes during the vegetative period $(A)$ and the reproductive period (B). 
The analysis of variance revealed a significance for the time factor of plant collection for the traits leaf area $\left(\mathrm{L}_{\mathrm{a}}\right)$, leaf dry weight $\left(W_{1}\right)$, stem dry weight $\left(W_{s}\right)$, root dry weight $\left(W_{r}\right)$, and seeds dry weight $\left(W_{g}\right)$ at $5 \%$ probability by the F test (Table 1).

In all treatments, the total dry weight production $\left(W_{t}\right)$ fitted simple logistics, with a high coefficient of determination (>0.98), as shown in Figure 2B. Plants of all treatments showed a slow initial growth up to 42 days after emergence (DAE). Then, they entered the phase of intense growth, as verified by the increase in $\mathrm{W}_{t}$. Plants grown from high vigor seeds were predominant in the production of total dry weight compared to plants grown from low vigor seeds (Figure 2B). From $70 \mathrm{DAE}$, there was a higher production of dry weight by plants kept at field capacity, followed by plants exposed to a water restriction period. Plants from seeds of low vigor reached lower $\mathrm{W}_{\mathrm{t}^{\prime}}$ however, when exposed to water restriction suffered a marked reduction in the production of $\mathrm{W}_{\mathrm{t}}$ compared to those of the other treatments (Figure 2B).

Plants grown from high vigor seeds exposed to water restriction and plants grown from low vigor seeds at field capacity and exposed to water restriction suffered a reduction of approximately 14,20 and 41\%, respectively, compared to plants grown from high vigor seeds at field capacity.

The use of high vigor seeds provided the plants with a high dry weight allocation even when exposed to water restriction conditions. Seed vigor has a close relationship with the capacity of establishing normal seedlings under different environmental conditions. In this sense, seeds with a greater vigor provide a faster establishment of plants, in addition to obtaining a more suitable stand. Plants that occupy the farming environment in a better way can take advantage from better environmental resources, allowing a greater dry weight accumulation capacity and a greater productive potential (Pimentel et al., 2017).

However, the reduction in dry weight due to water deficit may result from the delay in the physiological processes of hydrolysis and mobilization of reserves, or be linked to the production of free radicals, which promote lipid peroxidation, responsible for the degradation of membranes and electrolyte leakage (Greggains et al., 2000). Such metabolic changes can occur in both high and low vigor seeds, however, due to their lower responsiveness, low vigor seeds tend to suffer more significant damage, as observed in this case.

Table 1. Summary of the analysis of variance with the mean squares of leaf area $\left(L_{a}\right)$, leaf dry weight $\left(W_{1}\right)$, stem dry weight $\left(\mathrm{W}_{\mathrm{s}}\right)$, root dry weight $\left(\mathrm{W}_{\mathrm{r}}\right)$, and seeds dry weight $\left(\mathrm{W}_{\mathrm{g}}\right)$.

\begin{tabular}{|c|c|c|c|c|c|c|}
\hline \multirow{2}{*}{ SV } & \multirow{2}{*}{$\mathrm{GL}$} & \multicolumn{5}{|c|}{ Means squares } \\
\hline & & $\mathrm{L}_{\mathrm{a}}$ & $\mathrm{W}_{1}$ & $\mathrm{~W}_{\mathrm{s}}$ & $W_{r}$ & $\mathrm{~W}_{\mathrm{g}}$ \\
\hline Vigor (V) & 1 & $0.0000128 \mathrm{~ns}$ & $0.0418 n s$ & $0.0486 n s$ & $0.000231 \mathrm{~ns}$ & $0.482 *$ \\
\hline Water Regime (WR) & 1 & $0.0000811^{*}$ & $0.134 *$ & $0.393^{*}$ & $0.0266^{*}$ & $0.522 *$ \\
\hline Collections (C) & 7 & 0.000389* & 4.986* & $4.760 *$ & $0.287^{*}$ & $17.224^{*}$ \\
\hline $\mathrm{V} \times \mathrm{C}$ & 7 & $0.00000152^{\mathrm{ns}}$ & $0.0871^{*}$ & $0.131^{*}$ & $0.00236^{\mathrm{ns}}$ & $0.419 *$ \\
\hline WR $\times C$ & 7 & $0.00000984^{*}$ & $0.0426^{\mathrm{ns}}$ & $0.0693^{\mathrm{ns}}$ & $0.00384^{\text {ns }}$ & $0.246^{*}$ \\
\hline$V \times W R$ & 1 & $0.0000382 *$ & $0.0638^{\mathrm{ns}}$ & $0.0346^{\mathrm{ns}}$ & $0.0182^{*}$ & $0.154^{\text {ns }}$ \\
\hline$V \times W R \times C$ & 7 & $0.00000402^{\text {ns }}$ & $0.0488^{\text {ns }}$ & $0.0131^{\mathrm{ns}}$ & $0.00261^{\mathrm{ns}}$ & $0.142^{\text {ns }}$ \\
\hline Resídue & 96 & 0.00000384 & 0.0260 & 0.0998 & 0.0336 & 0.00321 \\
\hline Total & 127 & & & & & \\
\hline Average & & 0.00644 & 0.711 & 0.693 & 0.494 & 0.0169 \\
\hline CV (\%) & & 30.40 & 22.76 & 45.59 & 37.08 & 33.40 \\
\hline
\end{tabular}

Level of significance $(P=* 5 \%)$. 

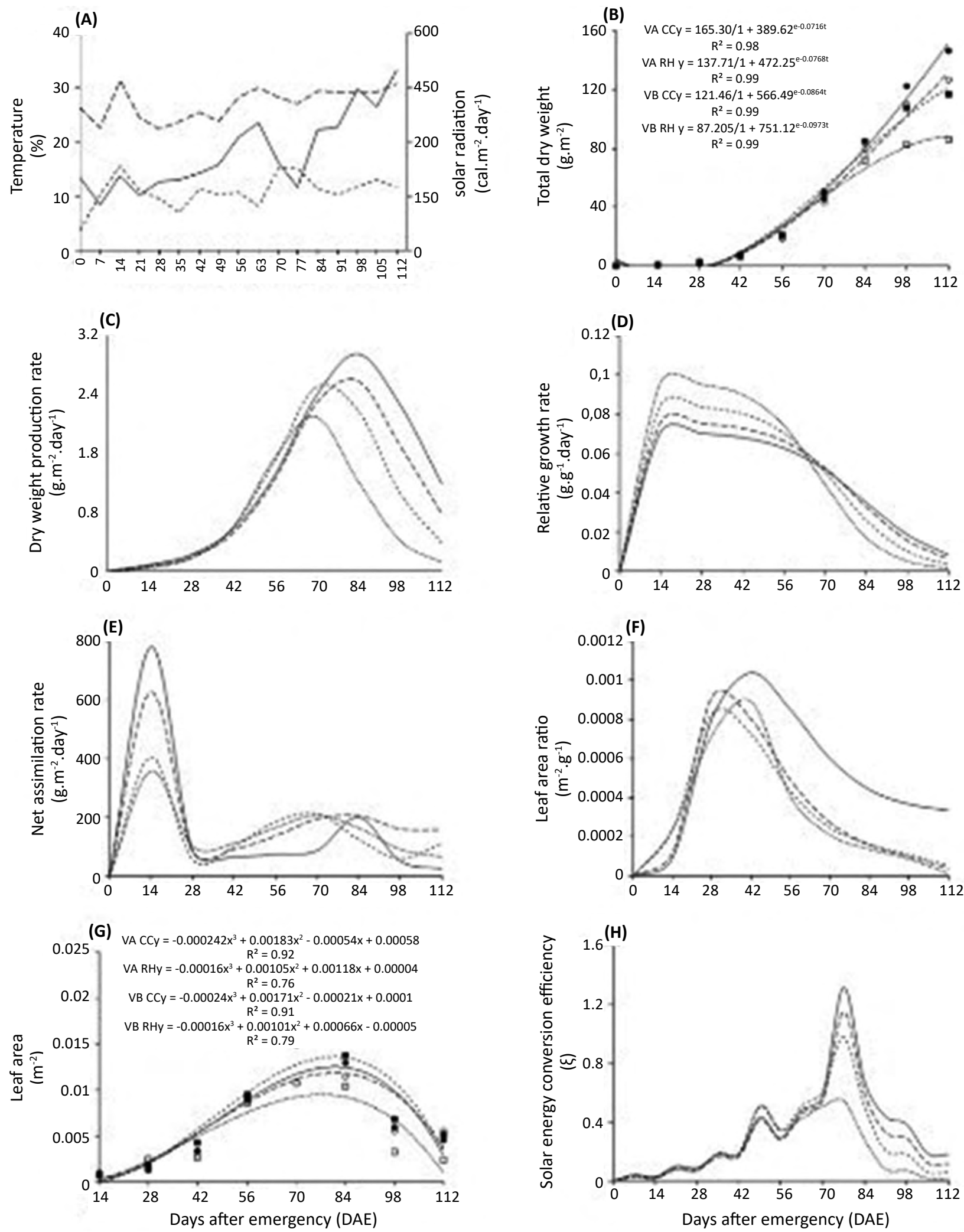

High vigor at field capacity (

), high vigor under water restriction ( under water restriction

- =), low vigor at field capacity ( ), and low vigor

Figure 2. Maximum and minimum temperatures, solar radiation $(A)$, total dry weight $(B)$, dry weight production rate $(C)$, relative growth rate $(D)$, net assimilation rate $(E)$, leaf area ratio $(F)$, leaf area $(G)$, and $(H)$ solar energy conversion efficiency of wheat cultivars grown from seeds with different seed vigor levels. 
Dry weight production rate values $\left(\mathrm{C}_{\mathrm{t}}\right)$ remained low up to $42 \mathrm{DAE}$, corroborating the low total dry weight production over the same period, as shown in Figure $2 C$. The low values of $W_{t}$ and $C_{t}$ during this phase are due to the reduced leaf area and the volume of roots dedicated to the absorption of water and nutrients. The maximum values of $C_{t}$ were obtained at 84 DAE for plants grown from high vigor seeds and at 70 DAE for plants grown from low vigor seeds, which reached lower values. Plants subjected to water restriction reached lower values of $C_{t}$ than plants kept at field capacity, both for plants grown from high vigor seeds and from low vigor seeds.

In this sense, plants grown from high vigor seeds exposed to water restriction suffered a reduction of approximately $12 \%$ in the maximum values of $C_{t^{\prime}}$, while plants grown from low vigor seeds at field capacity exposed to water restriction reduced their maximum $C_{t}$ values by 15 and $29 \%$, respectively.

Plants grown from high vigor seeds and plants kept at field capacity reached high $\mathrm{C}_{\mathrm{t}}$ values, reaching approximately $3.0 \mathrm{~g} . \mathrm{m}^{-2} \cdot \mathrm{d}^{-1}$, which indicates a greater increase in dry weight per unit area and time. It is noteworthy that plants grown from high vigor seeds were more efficient in the use of medium resources, since they reached superiority in the values of $C_{t}$.

As observed in the study by Endres et al. (2010) the imposition of water restriction may have caused stomata closure, contributing to the reduction of photosynthesis processes, which is directly responsible for the accumulation of dry weight from the synthesis of carbohydrates, which may explain the lower $C_{t}$ values obtained mainly by plants from low vigor seeds and when subjected to stress. In this sense, it is worth mentioning that seeds with high vigor tend to have greater tolerance to adverse factors such as temperature, water availability and characteristics inherent to the soil (Silva et al., 2016) which justifies the results obtained.

The relative growth rate $\left(R_{w}\right)$ reached the maximum value at $14 \mathrm{DAE}$, with subsequent decreases up to $112 \mathrm{DAE}$ for plants of all treatments (Figure 2D). Initially, at $14 \mathrm{DAE}$, plants grown from low vigor seeds, in both water conditions, reached higher values of $R_{w}$. However, from $70 \mathrm{DAE}$, there was an inversion in values: from this point, plants grown from high vigor seeds obtained higher $\mathrm{R}_{\mathrm{w}}$ values.

The net assimilation rate $\left(E_{a}\right)$ for plants of all treatments reached two peaks during the cycle (Figure 2E). The first peak of $E_{a}$ occurred at 14 DAE. It was mainly related to the predominance of young leaves, which have a high photosynthetic capacity. The second peak of $E_{a}$ occurred at $70 \mathrm{DAE}$ for plants grown from low vigor seeds, regardless of water condition, and for plants grown from high vigor seeds exposed to water restriction. Plants grown from high vigor seeds kept at field capacity reached the second peak at 84 DAE. The occurrence of the second peak of $E_{a}$ is related to the emergence of reproductive organs and the subsequent formation and maturation of seeds, preferential metabolic drains with a high mobilizing capacity of assimilates.

The positive effect of seed vigor on the values of $E_{a}$ at the beginning of plant cycle is perceptible. At 14 DAE, plants grown from high vigor seeds, regardless of water status, reached superior values. Plants grown from high vigor seeds kept at field capacity increased by 48 and 54\% compared to plants grown from low vigor seeds exposed to water restriction and at field capacity, respectively.

The net assimilation rate reflects the increase in plant material per unit leaf area over time, that is, it corresponds to the efficiency of the plant in the production of dry matter (Marafon, 2012). In this case, the higher values obtained by plants from seeds with high vigor may come from the greater speed in the metabolic processes that have these seeds, which results in faster and more uniform germination in addition to higher growth rates, which may explain the greater increase of plant material in these plants.

The leaf area ratio $\left(\mathrm{F}_{\mathrm{a}}\right)$ reached maximum values at the beginning of the plant development cycle (Figure $2 \mathrm{~F}$ ). There was a temporal-quantitative difference in the values of $F_{a}$ between plants of the different treatments. Plants grown from high vigor seeds exposed to water restriction and plants grown from low vigor seeds kept at field capacity reached maximum values of $F_{a}$ at 28 DAE. Plants grown from high vigor seeds field capacity, as well as plants grown from low vigor seeds exposed to water restriction, reached their maximum values at 42 DAE. Plants grown from high vigor seeds at field capacity reached a superiority in the values of $F_{a}$. There was an increase of 12,20 and $14 \%$ compared to plants 
grown from high vigor seeds exposed to water restriction and plants grown from low vigor seeds exposed to water restriction, as well as for plants kept at field capacity, respectively.

Leaf area values $\left(\mathrm{L}_{\mathrm{a}}\right)$ were similar up to $42 \mathrm{DAE}$ for plants of all treatments (Figure $2 \mathrm{G}$ ). Subsequently, plants grown from high vigor seeds, regardless of water condition, and plants grown from low vigor seeds at field capacity maintained a similar tendency. However, plants grown from low vigor seeds subjected to water restriction had low leaf area values.

According to Taiz and Zeiger (2013), up to a certain limit, the leaf area increases according to the greater availability of water in the soil, which allows the turgor of the leaves, thus resulting in greater leaf expansion and photosynthetic efficiency, with a pronounced decrease at the end of the plant cycle, when the senescence of the leaves occurs. In this sense, the authors also point out that one of the strategies for the protection of plants against water deficit is to reduce the leaf area, which limits perspiration and keeps the water supply for a longer period. In addition to water restriction, there is also the effect of seed vigor. In this context, seeds with high vigor have faster and more uniform emergence, and seedlings with greater growth (Vanzolini and Carvalho, 2002), which directly influences the achievement of a greater leaf area and accumulation of dry matter (Kolchinski et al., 2006).

The efficiency of the solar energy conversion $(\xi)$ presented differential responses between plants of the different treatments. The maximum values were reached approximately at $80 \mathrm{DAE}$ (Figure $2 \mathrm{H}$ ). Plants grown from high vigor seeds at field capacity reached the highest values of $\xi(1.32 \%)$, corresponding to an increase of approximately 12,26 and $59 \%$ in relation to plants grown from high vigor seeds subjected to water restriction and plants grown from low vigor seeds at field capacity and exposed to water restriction, respectively.

According to Harrison et al. (2011), the efficiency of conversion of solar energy is directly influenced, among other factors, by the leaf area. In this sense, it is observed that plants from seeds of low vigor and kept under water restriction obtained the lowest values of ratio of leaf area and leaf area, which explains the lower $\xi$ results for plants in these conditions, which shows the influence of water restriction and seed vigor due to plant growth.

By analyzing the dry weight partitioning between the different plant structures, it was verified that, in plants grown from high vigor seeds (Figure $3 \mathrm{~A}, \mathrm{~B}$ ), regardless of water condition, the partitioning of assimilates to the stem was intense during the initial period of development of wheat plants (between 28 and $70 \mathrm{DAE}$ ) compared to seedlings grown from low vigor seeds (Figure 3C,D). The change in drain preference is expected over plant ontogeny. Initially, the preferential drainage is young roots and leaves under development. As the cycle progresses, preferential metabolic drains become the vegetative and reproductive parts, the latter being the definitive metabolic drain (Lopes and Lima, 2015). However, under environmental stress conditions, the preferentiality for drainage can be modified, and crop yield can be negatively affected (Aumonde et al., 2017).

Harvest index values for seedlings grown from both vigor levels were higher when plants were kept at field capacity compared to plants exposed to water restriction (Table 2).

For field water capacity, the plants grown from high vigor seeds were superior to plants grown from low vigor seeds, reaching a superiority of $11 \%$ in the harvest index. By analyzing the plants exposed to water restriction, there were no significant differences between plants grown from high or low vigor seeds. In this sense, Marcos-Filho and Kikuti (2006) emphasize that the use of vigorous seeds is justified to ensure the proper establishment of the plant stand, even if there are no consistent responses regarding the final crop production.

In general, it can be observed that the vigor of the seeds as well as the imposition of water restriction influenced the characteristics related to the growth and assimilate partitioning in plants. It was observed that plants from seeds of high vigor and kept under field capacity showed higher values for most of the growth variables analyzed. In this sense, plants from seeds with high vigor tend to tolerate conditions of stress and adversity, thus obtaining better results, although the imposition of the stressful condition also affects these plants. Thus, the use of highly vigorous seeds is vital for a better performance of plants in adverse conditions, however, it is an excellent alternative even when soil moisture conditions are ideal for the development of wheat crop. 

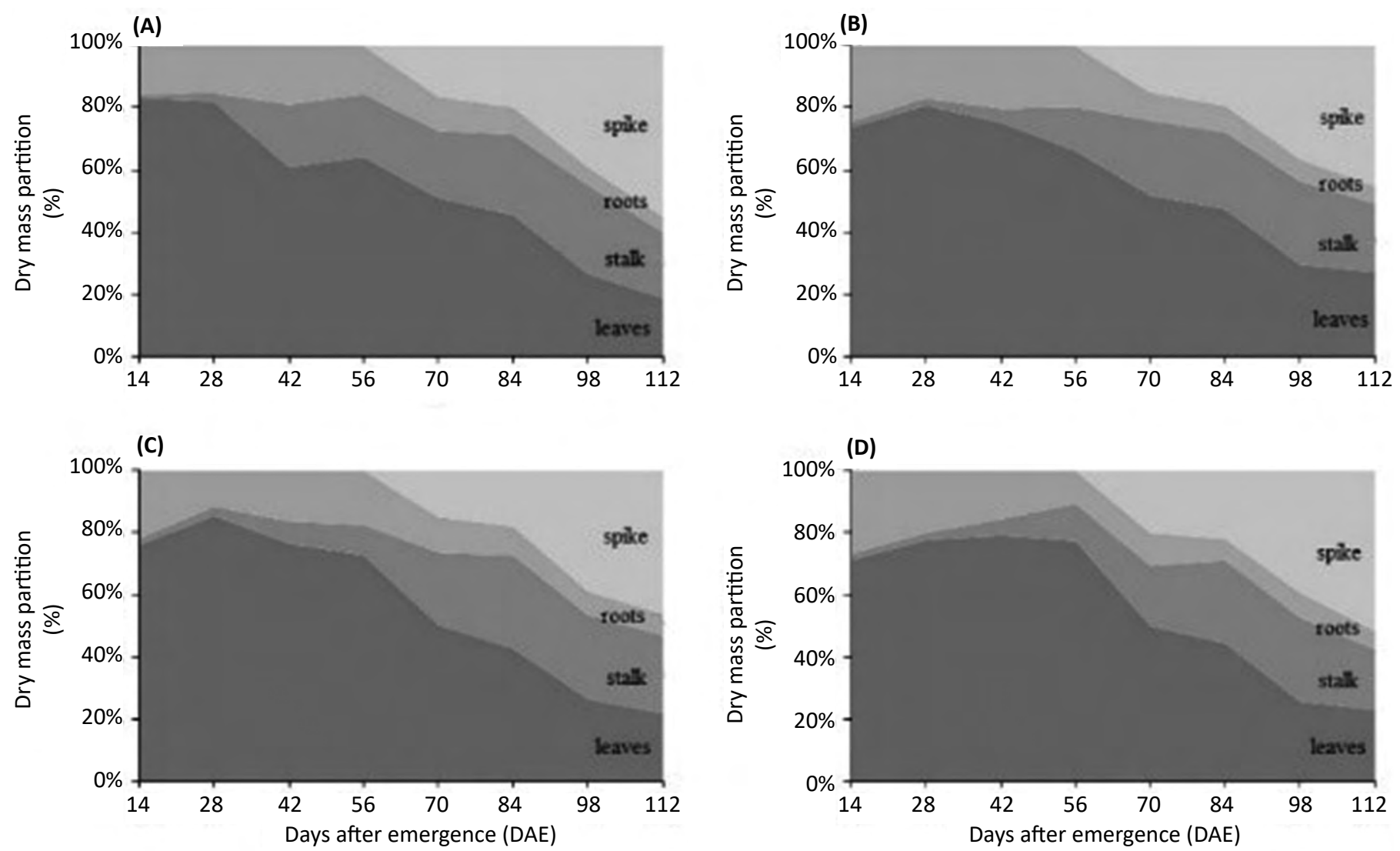

High vigor at field capacity (A), high vigor under water restriction (B), low vigor at field capacity (C), and low vigor under water restriction (D).

Figure 3. Partition of dry weight between wheat plants (T. aestivum L.) grown from seeds with different vigor levels subjected to different water regimes.

Table 2. Unfolding of the simple effects of the interaction between vigor levels and water regimes for the variable harvest index.

\begin{tabular}{ccc}
\hline \multirow{2}{*}{ Level of vigor } & \multicolumn{2}{c}{ Harvest index } \\
\cline { 2 - 3 } & Field capacity & Water restriction \\
\hline High vigor & $0.55 \mathrm{aA} *$ & $0.45 \mathrm{aB}$ \\
Low vigor & $0.49 \mathrm{bA}$ & $0.44 \mathrm{aB}$ \\
\hline CV (\%) & 4.57 & \\
\hline
\end{tabular}

*Means followed by the same lowercase letter in column and uppercase in lines do not differ by Tukey test $(p \leq 0.05)$.

\section{CONCLUSIONS}

Total dry weight production, dry weight production rate, net assimilation rate, leaf area index, leaf weight ratio and solar energy conversion efficiency were higher for plants derived from high vigor seeds and maintained under field capacity. The accumulation of dry weight in the stem is higher for plants originating from seeds with high vigor.

The yield is higher for plants originating from seeds of high vigor in relation to those of low vigor in soil maintained in the field capacity. However, when subjected to stress, plants with high vigor seeds did not differ from those with low vigor. 


\section{ACKNOWLEDGEMENTS}

This work was carried out with the support of CNPq, Conselho Nacional de Desenvolvimento Cientifico $e$ Tecnológico, Brazil.

Thanks to CNPq for the research productivity grant - PQ2 - granted to the last author, and for the doctoral grant granted to the first author.

\section{REFERENCES}

APPELS, R.; EVERSOLE, K.; FEUILLET, C.; KELLER, B.; ROGERS, J.; STEIN, N.; ... and RONEN, G. Shifting the limits in wheat research and breeding using a fully annotated reference genome. Science, v.361, n.6403, 2018. https://science.sciencemag.org/ content/361/6403/eaar7191

ASGHER, M.; PER, T.S; MASOOD, A.; FATMA, M.; FRESCHI, L.; CORPAS, F.J; KHAN, N.A. Nitric oxide signaling and its crosstalk with other plant growth regulators in plant responses to abiotic stress. Environmental Science and Pollution Research, v.24, n.3, p.22732285, 2017. https://www.ncbi.nlm.nih.gov/pubmed/27812964

AUMONDE, T.Z.; PEDÓ, T.; MARTINAZZO, E.G.; MONTEIRO, M.A.; KOCH, F. Análise de crescimento e do vigor como ferramenta de avaliação do estresse ambiental. In: AUMONDE, T.Z.; PEDÓ, T.; MARTINAZZO, E.G.; VILLELA, F.A. Estresses ambientais e a produção de sementes: Ciência e aplicação. Pelotas, RS: Ed. Cópias Santa Cruz, 2017. p.257-275.

BARRS, H.D.; WEATHERLEY, P.E. A re-examination of the relative turgidity technique for estimating water deficits in leaves. Australian Journal of Biological Sciences, v.15, p.413-428, 1962. https://www.scirp.org/(S(351jmbntvnsjt1aadkposzje))/reference/ ReferencesPapers.aspx?ReferencelD $=1881811$

BORÉM, A.; SCHEEREN, P.L. Trigo: do plantio à colheita. Viçosa, MG: Editora UFV, 2015. 260p.

BRASIL. Ministério da Agricultura, Pecuária e Abastecimento. Regras para análise de sementes. Ministério da Agricultura, Pecuária e Abastecimento. Secretaria de Defesa Agropecuária. Brasília: MAPA/ACS, 2009. 399p. http:// https://www.gov.br/agricultura/ptbr/assuntos/insumos-agropecuarios/arquivos-publicacoes-insumos/2946_regras_analise_sementes.pdf

CARVALHO, F.E.L.; LOBOL, A.K.M.; BONIFÁCIO, A.; MARTINS, M.O.; LIMA-NETO, M.C.; SILVEIRA, J.A.G. Aclimatação ao estresse salino em plantas de arroz induzida pelo pré-tratamento com $\mathrm{H}_{2} \mathrm{O}_{2}$. Revista Brasileira de Engenharia Agrícola e Ambiental, v.15, p.416-423, 2011. https://www.scielo.br/scielo.php?script=sci_arttext\&pid=S1415-43662011000400014

CQFS. COMISSÃO DE QUÍMICA E FERTILIDADE DO SOLO (RS/SC). Manual de adubação e calagem para os estados do Rio Grande do Sul e Santa Catarina. 10 ed., Porto Alegre: Sociedade Brasileira de Ciência do Solo/Núcleo Regional Sul, 2004. 400p.

DEMIRBAS, A. Relationships between lignin contents and fixed carbon contents of biomass samples. Energy Conversion Management, v.44, p.1481-1486, 2003. https://www.sciencedirect.com/science/article/abs/pii/s0196890402001681

ENDRES, L.; SOUZA, J.L.; TEODORO, I.; MARROQUIM, P.M.G.; SANTOS, C.M.D; BRITOS, J.E.D. Gas exchange alteration caused by water deficit during the bean reproductive stage. Revista Brasileira de Engenharia Agrícola e Ambiental, v.14, p.11-16, 2010. https://www.scielo.br/scielo.php?script=sci_arttext\&pid=S1415-43662010000100002

FURLAN, A.; LIANES, A.; LUNA, V.; CASTRO, S. Physiological and biochemical responses to drought stress and subsequent rehydration in the symbiotic association Peanut-Bradyrhizobium sp. Agronomy, v.2012, n.318083, p.1-8, 2012. https://www.hindawi.com/ journals/isrn/2012/318083/

GALLÉ, A.; SARASA-FLOREZ, I.; AOUOUAD, H.E.; FLEXAS, J. The Mediterranean evergreen Quercus ilex and the semi-deciduous Cistus albidus differ in their leaf gas exchange regulation and acclimation to repeated drought and re-watering cycles. Journal of Experimental Botany, v.62, n.14, p.5207-5216, 2011. https://www.ncbi.nlm.nih.gov/pubmed/21813795

GOERGEN, P.C.H.; KRÜGER, C.A.M.B.; BIANCHI, V.; SILVA, I.W.; GEHRKE, I.T.S.; CORRÊA, J.B.; SILVA, J.A.G. Effects of Schinus terebinthifolius extracts on the control of Sitophilus species in stored wheat grains. African Journal of Agricultural Research, v.12, p.3556-3561, 2017. https://academicjournals.org/journal/AJAR/article-full-text-pdf/CFDE02567147 
GREGGAINS, V., FINCH-SAVAGE, W.E., QUICK, W.P.; ATHERTON, N.M. Metabolism induced free radical activity does not contribute significantly to loss of viability in moist stored recalcitrant seeds of contrasting species. New Phytologist, v.148, p.267-276, 2000. https://nph.onlinelibrary.wiley.com/doi/abs/10.1046/j.1469-8137.2000.00757.x

HARRISON, M.T.; EVANS, J.R.; DOVE, H.; MORRE, A.D. Dual-purpose cereals: can the relative influences of management and environment on crop recovery and grain yield be dissected? Crop and Pasture Science, v.62, n.11, p. 930-946, 2011. https:// www.researchgate.net/publication/262961409_Dual-purpose_cereals_Can_the_relative_influences_of_management_and_ environment_on_crop_recovery_and_grain_yield_be_dissected

HU, H.; XIONG, L. Genetic engineering and breeding of drought-resistant crops. Annual Review of Plant Biology, v.65, p.715-741, 2014.https://www.researchgate.net/publication/259244375_Genetic_Engineering_and_Breeding_of_Drought-Resistant_Crops

HUSSAIN, M.; FAROOQ, S.; HASAN, W.; UI-ALLAH, S.; TANVEER, M.; FAROOQ, M.; NAWAZ, A. Drought stress in sunflower: physiological effects and its management through breeding and agronomic alternatives. Agricultural Water Management, v.201, p.152-166, 2018. https://www.sciencedirect.com/science/article/abs/pii/S0378377418300787

KOLCHINSKI, E.M.;SCHUCH, L.O.B.;PESKE,S.T.Crescimento inicial de soja em função dovigor dassementes. CurrentAgriculturalScience and Technology, v.12, 2006. https://periodicos.ufpel.edu.br/ojs2/index.php/CAST/article/view/4513\#: :text=CRESCIMENTO\%20 INICIAL\%20DE\%20SOJA\%20EM\%20FUN\%C3\%87\%C3\%830\%20D0\%20VIGOR\%20DAS\%20SEMENTES,-Eliane\%20Maria\%20 Kolchinski\&text=Utilizou\%2Dse\%20a\%20cultivar\%20de\%20soja\%2C\%20BRS\%20154.\&text=0\%20alto\%20vigor\%20das\%20 sementes,a\%2020\%20DAE\%20em\%202001

LANGARO, A.C. Alterações fisiológicas na cultura do tomateiro devido à deriva simulada de herbicidas. Revista Brasileira de Herbicidas, v.13, n.1, p.40-46, 2014. http://www.rbherbicidas.com.br/index.php/rbh/article/view/282\#: :text=A\%20deriva\%20 do\%20herbicida\%20glifosato,de\%20tomate\%2C\%20acarretando\%20estresse\%20oxidativo

LIMA, T.C.; MEDINA, P.F.; FANAN, P. Avaliação do potencial fisiológico de sementes de trigo pelo teste de envelhecimento acelerado. Revista Brasileira de Sementes, v.28, n.1, p.106-113, 2006. https://www.scielo.br/scielo.php?pid=S010131222006000100015\&script=sci_abstract\&tlng=pt

LISAR, S.Y.S.; MOTAFAKKERAZAD, R.; HOSSAIN, M.M.; RAHMAN, I.M.M. In: RAHMAN, M.; HASEGAWA, H. (ed). Water stress. InTech: IRijeka, Croatia, 2012. p.1-14.

LOPES, N.F.; LIMA, M.G.S. Fisiologia da produção vegetal. Viçosa, MG: Ed. UFV, 2015. 492p.

MARAFON, A.C. Análise quantitativa de crescimento em Cana-de-açúcar: uma introdução ao procedimento prático. Aracaju, SE: Embrapa Tabuleiros Costeiros, 2012. 32p.

MARCOS-FILHO, J.; KIKUTI, A.L.P. Vigor de sementes de rabanete e desempenho de plantas em campo. Revista Brasileira de Sementes, v.28, n.3, p.44-51, 2006. https://www.scielo.br/scielo.php?script=sci_abstract\&pid=S010131222006000300007\&Ing=en\&nrm=iso\&tlng=pt\#: :text=0\%20experimento\%20de\%20campo\%20foi,para\%20a\%20cultura\%20 do\%20rabanete

MENG, S.; ZHANG, C.; SU, L.; LI, Y.; ZHAO, Z. Nitrogen uptake and metabolism of Populus simonii in response to PEG-induced drought stress. Environmental and Experimental Botany, v.123, p.78-87, 2016. https://www.sciencedirect.com/science/article/ abs/pii/S0098847215300332

MUNIZZI, A.; BRACCINI, A.L.; RANGEL, M.A.S.; SCAPIM, C.A.; ALBRECHT, L.P. Qualidade de sementes de quatro cultivares de soja, colhidas em dois locais no estado de Mato Grosso do Sul. Revista Brasileira de Sementes, v.32, n.1, p.176-185, 2010. https://www. scielo.br/scielo.php?pid=S010131222010000100020\&script=sci_abstract\&tlng=pt

OLIVEIRA, D.M.; SOUZA, A.M.; ROCHA, V.S.; ASSIS, J.C. Desempenho de genitores e populações segregantes de trigo sob estresse de calor. Bragantia, v.70, n.1, p.25-32, 2011. https://www.scielo.br/pdf/brag/v70n1/v70n1a05

PEDROSO, D.C.; TUNES, L.M.; BARBIERI, A.P.; BARROS, A.S.A.; MUNIZ, M.F.B.; MENEZES, V.O. Envelhecimento acelerado em sementes de trigo. Ciência Rural, v.40, n.11, p.2389-2392, 2010. https://www.scielo.br/pdf/cr/2010nahead/a760cr3738.pdf

PIMENTEL, J.R.; MONTEIRO, M.A.; AUMONDE, T.Z.; PEDÓ. T. In: AUMONDE, T.Z.; PEDÓ, T.; MARTINAZZO, E.G.; VILLELA, F.A. Estresses ambientais e a produção de sementes: ciência e aplicação. Pelotas, RS: Ed. Cópias Santa Cruz, 2017. p.89-114. 
RADFORD, P.J. Growth analysis formulae: their use and abuse. Crop Science, v.7, n.3, p.171-175, 1967. https://acsess.onlinelibrary. wiley.com/doi/abs/10.2135/cropsci1967.0011183X000700030001x

RICHARDS, F.J. The quantitative analysis of growth. In: STEWWARD, F.C. (ed). Plantphysiology, New York: Academic Press, 1969. p.3-76.

SANTOS, D.; GUIMARÃES, V.F.; KLEIN, J.; FIOREZE, S.M.; MACEDO-JÚNIOR, E.K. Cultivares de trigo submetidas a déficit hídrico no início do florescimento, em casa de vegetação. Revista Brasileira de Engenharia Agrícola e Ambiental, v.16, n.8, p.836-842, 2012. https://www.scielo.br/scielo.php?script=sci_arttext\&pid=S1415-43662012000800004

SANTOS, S.M.C.; ANTONANGELO, J.A.; DEUS, A.C.F.; FERNANDES, D.M. Perdas de amônia por volatilização em resposta a adubação nitrogenada do feijoeiro. Revista de Agricultura Neotropical, v.3, p.16-20, 2016. https://periodicosonline.uems.br/index.php/ agrineo/article/view/545/926

SILVA, R.C.D., GRZYBOWSKI, C.R.D.S.; PANOBIANCO, M. Vigor de sementes de milho: influência no desenvolvimento de plântulas em condições de estresse salino. Revista Ciência Agronômica, v.47, p.491-499, 2016. https://www.scielo.br/scielo.php?pid=S1806$66902016000300491 \&$ script=sci_arttext

SIMONI, F.; COSTA, R.S.; FOGAÇA, C.A.; GEROLINETO, E. Sementes de Sorghum bicolor L. Gramineae, submetidas ao estresse hídrico simulado com PEG (6000). Revista de Biologia e Ciência da Terra, v.11, n.1, p.188-192, 2011. http://joaootavio.com.br/bioterra/ workspace/uploads/artigos/artigo_bioterra_v11_n1_2011_22-5155fdc33a349.pdf

SINMONTACCHI, M.; GALATRO, A.; ARTUSO-RAMOS, F.; SANTA-MARIA, G.E. Plant survival in a changing environment: the role of nitric oxide in plant responses to abiotic stress. Frontiers in Plant Science, v.6, n.977, 2015. https://www.ncbi.nlm.nih.gov/pmc/ articles/PMC4637419/

TAIZ, L.; ZEIGER, E. Fisiologia Vegetal. 5.ed. Porto Alegre: ARTMED, 2013. 848p.

TATAGIBA, S.D.; XAVIER, T.M.T; TORRES, H.; PEZZOPANE, J.E.M.; CECÍLIO, R.A.; ZANETTI, S.S. Determinação da máxima capacidade de retenção de água no substrato para produção de mudas de eucalipto em viveiro. Floresta, v.45, n.4, p.745-754, 2015. https:// revistas.ufpr.br/floresta/article/view/38334/26946

TEIXEIRA, D.T.F.; NOGUEIRA, G.A.S; MALTAROLO, B.M.; ATAÍDE, W.L.S.; OLIVEIRA-NETO, C.F. Alterações no metabolismo do nitrogênio em plantas de noni sob duas condições hídricas. Enciclopédia Biosfera, Centro Científico Conhecer, v.11, n.22, p.89-106, 2015. http://www.conhecer.org.br/enciclop/2015c/agrarias/Alteracoes\%20no\%20metabolismo.pdf

USDA. Soil taxonomy: a basic system of soil classification for making and interpreting soil surveys. Washington: USDA, 1999. 866p.

VANZOLINI, S.; CARVALHO, N.M. Efeito do vigor de sementes de soja sobre o seu desempenho em campo. Revista Brasileira de Sementes, v.24, n.1, p.33-41, 2002. https://www.scielo.br/scielo.php?script=sci_arttext\&pid=S0101-31222002000100006.

ZADOKS, J.C.; CHANG, T.T.; KONZAC, C. F. A decimal code for the growth stages of cereals. Weed Research, v. 14, p. 415-421, 1974. https://www.semanticscholar.org/paper/A-decimal-code-for-the-growth-stages-of-cereals-J.-T.E./ a54ed778dfd323b1de183662436cde2140976f95.

YAN, W.; HOLLAND, J.B. A heritability-adjusted GGE biplot for test environment evaluation. Euphytica, v.171, p.355-369, 2010. https://link.springer.com/article/10.1007/s10681-009-0030-5. 